\title{
Differentiation of Entamoeba histolytica/Entamoeba dispar by the Polymerase Chain Reaction in Stool Samples of Patients with Gastrointestinal Symptoms in the Sanliurfa Province
}

\author{
Şanlıurfa' da Gastrointestinal Semptomları Olan Hastaların Dışkı Örneklerinde Entamoeba \\ histolytica/Entamoeba dispar PGR ile Ayrımı
}

\author{
Fadile Yıldız Zeyrek1', Nevin Turgay², Aysegül Ünver², Şebnem Üstün³, Ulus Akarca³ ${ }^{3}$ Seray Töz² \\ 'Department of Microbiology, Faculty of Medicine, Harran University, Şanlıurfa, Turkey \\ ${ }^{2}$ Department of Parasitology, Faculty of Medicine, Ege University, İzmir, Turkey \\ ${ }^{3}$ Department of Gastroenterology, Faculty of Medicine, Ege University, İzmir, Turkey
}

\begin{abstract}
Objective: We aimed to diagnose amebiasis and also identify Entamoeba histolytica (E. histolytica) and Entamoeba dispar (E. dispar) in patients with gastrointestinal symptoms in an endemic region in Turkey.

Methods: Stool samples obtained from 181 patients with gastrointestinal symptoms from the Harran University Hospital of Sanliurfa were examined for the diagnosis of amebiasis by the three methods which are as follows:- In house polymerase chain reaction (PCR) targeting the 135 base pair region located on the small-subunit ribosomal RNA (SSU rRNA) gene to differentiate E. histolytica from E. dispar; and the commercial kit, RIDASCREEN ${ }^{\circledR}$ stool ELISA, that identifies Entamoeba sensu lato antigen and microscopical examination of Trichrome stained smears of stool samples.

Results: Positivity for E. histolytica/E. dispar complex was found to be 79 (43.6\%) by microscopy versus 83 (45.9\%) by PCR out of 181 stool samples. A total of 45 patients were found to be positive by the antigen detection method. PCR and microscopy were both positive in 59 samples. The number of patients infected with E. dispar (39.8\%) was found to be higher than E. histolytica (3.3\%) while 5 patients (2.8\%) had mixed E. histolytica+E. dispar infections according to PCR results.

Conclusion: Routine diagnosis of amebiasis by a combination of microscopy and antigen detection technique should be complemented with a PCR assay as a reference test for sensitive differentiation of both species. (Turkiye Parazitol Derg 2013; 37: 174-8)
\end{abstract}

Key Words: E. histolytica/E. dispar, PCR, ELISA, microscopy

Received: 01.04.2013

Accepted: 22.07.2013

\section{ÖZET}

Amaç: Çalışmamızda, endemik bir bölgede olan Şanlıurfa'da gastrointestinal semptomları olan hastalarda amebiazisin tanısı ve Entamoeba histolytica (E. histolytica) ve Entamoeba dispar (E. dispar) tanımlanmasını amaçladık.

Yöntemler: Şanlıurfa'da gastrointestinal semptomu olan 181 hastadan toplanan dışkı örnekleri amebiazis tanısı için aşağıda belirtilen 3 yöntemle incelenmişlerdir: E. histolytica/E. dispar ayıran "small-subunit (SSU) rRNA gen" bölgesinde yerleşen 135 bazlık bölgenin hedeflendiği in house PCR, Entamoeba sensu lato antijenini gösteren ticari kit RIDASCREEN ${ }^{\circledR}$ stool ELISA ve Trichrome boyama ile mikroskobik inceleme yöntemleri.

Bulgular: Yüz seksen bir dışkı örneğinin 83'ü $(\% 45,9)$ PCR ile ve 79’u $(\% 43,6)$ mikroskobi ile E. histolytica/E. dispar pozitif bulunmuştur. Kırk beş hasta, antijen saptama yöntemi ile pozitif bulunmuştur. Elli dokuz örnek ise PCR ve mikroskobi birlikte pozitif tespit edilmiştir. E. dispar $(\% 39,8)$ ile enfekte bulunan hastaların sayısı, E. histolytica $(\% 3,3)$ ile enfekte olanlara göre fazla bulunmuştur. Beş hastada $(\% 2,8)$ ise PCR ile E. histolytica+E. dispar mix enfeksiyonu saptanmıştır.

Sonuç: Amebiazisin rutin tanısında mikroskobi ve antijen saptama yöntemlerinin yanı sıra, her iki türün hassas olarak ayırımı için referans test olarak PCR'ın uygulanması önerilmektedir. (Turkiye Parazitol Derg 2013; 37: 174-8)

Anahtar Sözcükler: E. histolytica/E. dispar, PCR, ELIZA, mikroskopi

Geliş Tarihi: 01.04.2013

Kabul Tarihi: 22.07.2013

Address for Correspondence / Yazışma Adresi: Dr. Nevin Turgay, Department of Parasitology, Faculty of Medicine, Ege University, İzmir, Turkey Phone: +90232390 4716 E-mail: nevin.turgay@ege.edu.tr doi:10.5152/tpd.2013.39 


\section{INTRODUCTION}

Amebiasis causes up to 100.000 deaths annually all over the world. E. histolytica, known as the main agent of intestinal amebiasis causing amebic colitis and liver abscess, is morphologically identical with E. dispar, which is accepted as a non-pathogenic commensal parasite (1). Microscopy, stool culture, serological methods including antibody and antigen detection, and molecular tools such as polymerase chain reaction (PCR) are the methods for the diagnosis of amebiasis. Even though microscopy is still the most widespread diagnostic method of amebiasis, it is incapable of distinguishing E. histolytica from E. dispar and might cause false positive results (2). In vitro culturing and isoenzyme analysis of the parasite are not suitable or practical methods for performing routine diagnostic laboratories. More recently, new techniques for identification of the parasite, such as antigen detection by monoclonal antibodies or DNA detection by molecular methods, are used to distinguish the two species in stool samples (3-5). The World Health Organisation (WHO) suggests using accurate differential diagnosis of amoebic species in order to avoid unnecessary treatment applications (only $10 \%$ of Entamoeba infections really need treatment) (6).

The Sanliurfa province, located in Southeastern Turkey, is on the crossroads between the Mediterranean, Anatolian plateau, and Mesopotamia. The province is situated in a semi-arid plain at 550 $\mathrm{m}$. The average temperature is $18.1^{\circ} \mathrm{C}$; the lowest is $-12.4^{\circ} \mathrm{C}$ in February and highest is $46.5^{\circ} \mathrm{C}$ in August. The average annual relative humidity is $49 \%$ and rainfall is $463 \mathrm{~mm}^{3}$. (Turkish Government Statistical Records, Annual Report-2010). While a number of studies indicated that amebiasis has been endemic in the population, data avaliable about E. histolytica and E. dispar prevalances in this province are inadequate (7). The aim of the present study was to detect amoebae and identify $E$. histolytica in stool samples of patients with gastrointestinal symptoms by PCR, stool antigen detection kit and microscopy for the standardisation of diagnosis of amebiasis in routine and reference laboratories.

\section{METHODS}

\section{Sampling}

Stool samples were collected from 181 patients who were admitted to the Harran University Medical Faculty Microbiology Outpatient Clinic Laboratory between June 2005 and June 2006, with the clinical signs of amebiasis and having gastrointestinal symptoms such as diarrhea, bloody and/or mucous stool specimen, abdominal pain, nausea and/or vomiting. None of the patients had a history of travelling. The informed consent forms were collected prior to the sampling and patients who received any medication within the previous three weeks were excluded from the study. Direct smears were prepared soon after collection and stool samples were stored at $-80^{\circ} \mathrm{C}$. Frozen samples were transferred to the Ege University Medical Faculty Department of Parasitology laboratory on dry ice for performing ELISA and PCR procedures

\section{Microscopy}

Direct smears from samples were stained with Trichrome stain and slides were examined three times by different experienced microscopists independently (8).

\section{ELISA}

The RIDASCREEN ${ }^{\circledR}$ ELISA (R-Biopharm AG, Darmstadt, Germany, C1701) commercial kit, designed to detect Entamoeba sensu lato antigen qualitatively in stool samples, was used for antigen detection in stool samples according to the manufacturer's instructions.

\section{DNA extraction}

Genomic DNAs were extracted from 1 gram of stool samples using PSP ${ }^{\circledR}$ Spin Stool DNA Plus Kit (Invisorb ${ }^{\circledR}$ Invitek) according to the manufacturer's instructions. DNA samples were stored at $-20^{\circ} \mathrm{C}$ until PCR was performed.

\section{DNA amplification}

Genomic DNA was subjected to PCR using different forward and unique reverse primer sets for $E$. histolytica and $E$. dispar (E. dispar; Forward: 5'- TAC AAA GTG GCC AAT TTA TGT AAG TA-3', Reverse: 3'-CTGATCTATCAATCAGTTGGTAGT-5', E. histolytica Forward: 5'-GTACAAAATGGCCAATTCATTCAATG-3') which were described previously (3). The target sequence was 135 base pairs (bp) with 35\% and 34\% Guanin/Cytosine ratios for E. histolytica and E. dispar respectively in small-subunit (SSU) rRNA gene (9). E. histolytica and E. dispar positive control DNA's were kindly sent by Dr. Hugues Charest (Canada) and double distilled water was used as the negative control.

Amplification reactions were performed in $50 \mu \mathrm{L}$ volume with the mix 1X PCR buffer, $1.5 \mathrm{mM} \mathrm{MgCl}, 50 \mu \mathrm{M}$ dNTP, $0.6 \mathrm{mM}$ of primers (lontek ${ }^{\circledR}$, Istanbul-Turkey), 2.5U Taq DNA polymerase (Promega ${ }^{\circledR}, \# \mathrm{M} 8301$ ) and $10 \mu \mathrm{L}$ of genomic DNA sample. Amplification consisted of $15 \mathrm{~min}$ at $94^{\circ} \mathrm{C}$ for the first denaturation and 40 cycles of $30 \mathrm{sec}$ at $94^{\circ} \mathrm{C}, 60 \mathrm{sec}$ at an annealing temperature of $51^{\circ} \mathrm{C}$ and $40 \mathrm{sec}$ at $72^{\circ} \mathrm{C}$ followed by a final extension of $5 \mathrm{~min}$ at $72^{\circ} \mathrm{C}$. Aliquots of $10 \mu \mathrm{L}$ of PCR products were separated in 3\% agarose gels (AppliChem ${ }^{\circledR}, A 2114,0500$ ) using 1xTris-borate-EDTA buffer (TBE) and visualized after staining with ethidium bromide $(0.2 \mu \mathrm{g} / \mathrm{mL}-1)$. Amplification reactions for each sample were performed twice in a blinded fashion.

\section{Statistical analysis}

Results were analysed according to Analyse it Software (Analyseit Software Ltd, Leeds, UK). Statistical difference was analyzed using the X2 (chi-square) test. The concordance between the results was determined by using the kappa index measure of agreement. Evaluation of the test results was based on the sensitivity, specificity, positive and negative predictive values, and kappa index agreement. To quantify agreement between assays, PCR was used as the reference test. An A P value less than 0.05 was considered as statistically significant.

\section{RESULTS}

Among the 181 patients enrolled in the study, 82 (45.3\%) were female and 99 (54.7\%) were male, and the mean age of the patients were $25.35 \pm 17.2$ years. There was no significant correlation between age groups or gender and positivity for E. histolytica/E. dispar ( $\mathrm{p}>0.05)$.

Thirteen out of 181 patients were found to be infected with other parasites such as Giardia intestinalis (3.3\%), Blastocystis spp. (1.7\%), Entamoeba coli (1.1\%), Ascaris lumbricoides (0.6\%) and 
Dientamoeba fragilis $(0.6 \%)$ by microscopy. Among these 13 patients, 8 were coinfected with E. histolytica/E. dispar. Comparison of microscopy, ELISA and PCR results were shown in Table 1, 2 and 3. Of the three methods used in the present study, PCR was revealed as having the highest positivity rate with 83 positives (45.9\%) for $E$. histolytica/E. dispar complex. The results of microscopy with 79 positives (43.6\%) were almost in agreement with PCR. In comparison of the two tests; PCR and microscopy were both positive in 59 samples while 24 samples were positive only by PCR and 20 samples were positive only by microscopy. However, the antigen detection method (RIDASCREEN) revealed much less positivity with only 45 positives.

Differentiation of E. histolytica and E. dispar in 83 PCR positives was revealed in $6(7.2 \%)$ of the samples to be positive for E. histolytica versus 72 (86.7\%) positive for E.dispar. Five (6.0\%) samples were found to be coinfected with $E$. histolytica and E. dispar $(p<0.001)$. A typical PCR amplification is shown in Figure 1.

A total of 45 patients were found to be positive by the Entamoeba sensu lato antigen detection method. Thirty seven out of these 45 cases were also found to be positive by PCR (as E. histolytica and/or E. dispar). The difference between ELISA and PCR results for E. histolytica and/or E. dispar was found to be significant $(p=0.0001)$. Comparison of both techniques showed that agreement was $69.1 \%(K a p p a=0.36)$. The sensitivity and specificity of ELISA compared to PCR was $53 \%$ and $82.7 \%$ respectively (Table 4). Among the 83 samples positive for E. histolytica and/or E. dispar by PCR, 59 were positive by microscopy. However, 20 samples positive by microscopy were not confirmed with PCR. The difference between microscopy and PCR results for $E$. histolytica/E. disparwas significant $(p=0.0001)$. Comparison of both techniques showed $75.7 \%$ (Kappa=0.50) agreement. The sensitivity and specificity of microscopy compared to PCR was $71.1 \%$ and $79.6 \%$ respectively (Table 4 ).

\section{DISCUSSION}

Microscopical diagnosis of E. histolytica/dispar complex on stool samples depends on Trichrome staining and requires technical expertise because of the existence of apathogenic forms of amoeba, polymorphonuclear leucocytes (PNL) or artifacts that can be misdiagnosed. Moreover, E. histolytica and E. dispar cannot be differentiated by microscopy $(2,9,10)$. More efficient techniques that allow differentiation must be developed in order to avoid unnecessary treatment when $E$. dispar is present, as recommended by WHO (11).

In Turkey, diagnosis of amebiasis depends on microscopical examination with saline and iodine staining by technicians in most of the diagnostic laboratories. Trichrome staining method is only performed in certain specialised parasitology laboratories.

The incidence of $E$. histolytica/E. dispar by microscopy was found to be $0-17 \%$ and $2.5-13 \%$ in Turkey and in the Sanliurfa province, respectively, and differentiation between $E$. histolytica and $E$. dispar with antigen detection methods was performed in only a few studies. TechLab E. histolytica II EIA was performed in 380 stool samples from patients with gastrointestinal symptoms in two endemic cities of Eastern and Southeastern Turkey, and 14 (15.4\%) out of 91 microscopically positive specimens were found
Table 1. Comparison of Trichrome staining, PCR and ELISA results

\begin{tabular}{|c|c|c|}
\hline Methods & $\begin{array}{c}\text { Negative } \\
\text { (\%) }\end{array}$ & $\begin{array}{c}\text { Positive } \\
\text { (\%) }\end{array}$ \\
\hline Trichrome staining & $102(56.4)$ & $79(43.6)$ \\
\hline PCR & $98(54.1)$ & $83(45.9)$ \\
\hline E. histolytica & $175(96.7)$ & $6(3.3)$ \\
\hline E. histolytica+ E. dispar & $176(97.2)$ & $5(2.8)$ \\
\hline E. dispar & $104(57.4)$ & $72(39.8)$ \\
\hline Ridascreen & $136(75.1)$ & $45(24.9)$ \\
\hline
\end{tabular}

Table 2. Comparison of PCR and antigen detection method results

\begin{tabular}{|l|c|c|}
\hline PCR & Ag negative & Ag positive \\
\hline E. histolytica & 4 & 2 \\
\hline E. dispar & 39 & 33 \\
\hline E. histolytica+E. dispar & 3 & 2 \\
\hline Negative & 90 & 8 \\
\hline Ag: Antigen
\end{tabular}

Table 3. Comparison of PCR and Trichrome staining results

\begin{tabular}{|c|l|c|c|c|}
\hline \multicolumn{2}{|c|}{} & \multicolumn{3}{|c|}{ Trichrome } \\
\cline { 3 - 5 } \multicolumn{2}{|c|}{} & Positive & Negative & Total \\
\hline \multirow{3}{*}{ PCR } & Positive & 59 & 24 & 83 \\
\cline { 2 - 5 } & Negative & 20 & 78 & 98 \\
\cline { 2 - 5 } & Total & 79 & 102 & 181 \\
\hline
\end{tabular}

to be positive for E. histolytica (7). In another study; out of 87 suspected stool specimens from Sanliurfa, 19 (21.7\%) and 23 (26.4\%) were positive for E. histolytica/E. dispar by ELISA (Ridascreen ${ }^{\circledR}$ Entamoeba; R-Biopharm AG, Darmstadt, Germany) and microscopy respectively (12).

There have been many publications on amebiasis epidemiology in the past without differentiation of E. histolytica/E. dispar and the incidence was reported between $10 \%$ and $80 \%$ in different localities of the world in the 1990s (13). PCR-RFLP was used successfully for the first time in the differentiation of $E$. histolytica/E. dispar in 1991 (14) and then many studies were carried out nreporting that PCR was a specific and sensitive diagnostic method as well as a valuable tool for the molecular epidemiological studies $(9,12,15-19)$. PCR has also some disadvantages, such as the presence of PCR inhibitors and DNA damaging substances in the stool (5).

In one study, ninety-five stool samples from 84 patients have showed 68, 63 and 55 E.histolytica or E. dispar positives by PCR, microscopy and ELISA respectively. PCR and ELISA showed 85\% concordance and PCR was found to be more sensitive and specific than ELISA (9). In another study, microscopically positive 207 samples were differentiated as 5.7\% E. histolytica and 94.3\% E. dispar by PCR (10). Among 5378 travelers, 103 laboratoryconfirmed amebiasis cases were detected. The results of various diagnostic tests were compared and stool microscopy and ELISA 
Table 4. Evaluation of results of Trichrome staining and ELISA methods according to PCR

\begin{tabular}{|l|c|c|c|c|c|c|}
\hline & Sensitivity (\%) & Specifity (\%) & PV (\%) & NV (\%) & Agreement (\%) & Kappa index (\%) \\
\hline Trichrome & $71.1(56.9-85.2)$ & $79.6(66.0-93.1)$ & $74.7(60.3-89.0)$ & $76.5(63.0-89.9)$ & $75.7(64.0-87.3)$ & 50.9 \\
\hline ELISA & $53.0(38.8-67.1)$ & $82.7(69.0-96.2)$ & $72.1(56.8-87.0)$ & $67.5(54.5-80.0)$ & $69.1(57.4-80.0)$ & 36.4 \\
\hline $\begin{array}{l}\text { The values in parentheses represent 95\% Confidence Interval } \\
\text { PV: Positive predictive value NV: Negative predictive value }\end{array}$ \\
\hline
\end{tabular}

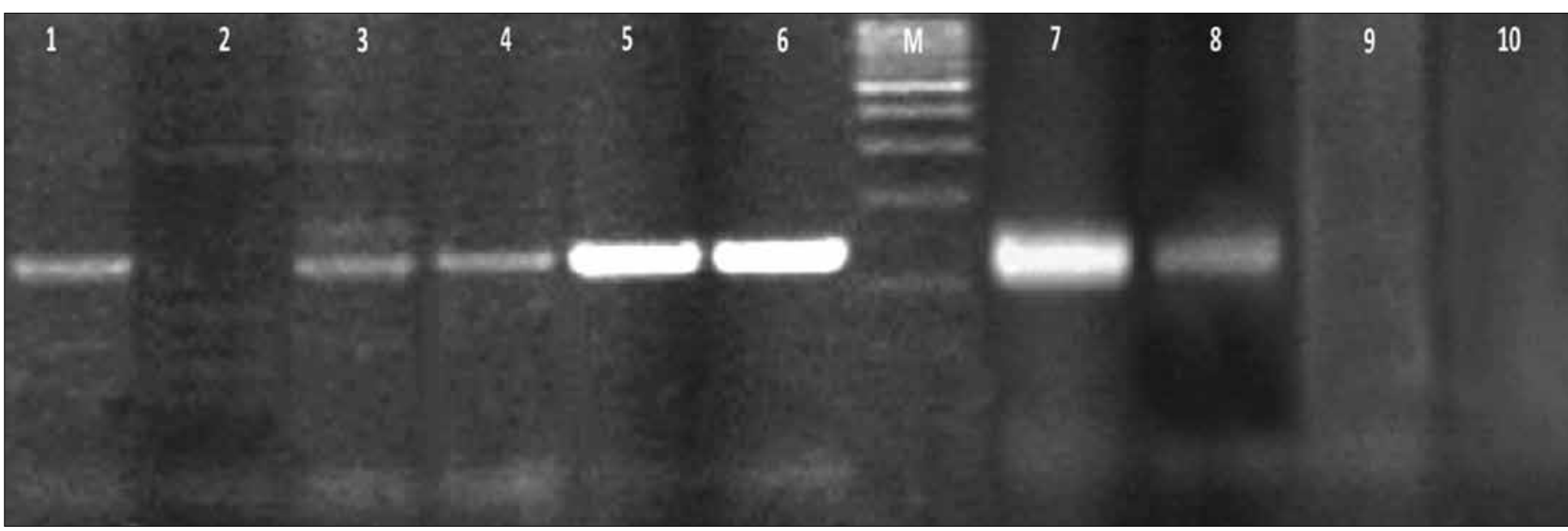

Figure 1. Sample amplification of stools containing or not containing E. histolytica and E. dispar. Lanes 1 and 6, E. dispar amplification; M: marker; lanes 7 to 10, E. histolytica amplification; lanes 1, 3, 4, 5 and 8, positive samples; lanes 6 and 7 positive control.

were found to be positive with 82.5 and $93.9 \%$, respectively. Positive samples detected by screening tests were also subjected to PCR with the detection of $9.7 \%$ and $88.3 \%$ of E. histolytica and $E$. dispar respectively (20). In contrast to many studies, Stark et al. (21) have reported that ELISA kits were 1000 to 10,000 times less sensitive than PCR and not useful for the detection of E. histolytica in stool samples from patients in non endemic geographical regions. We also have similar results in the present study. One hundred eighty one patients have showed 83, 79 and 45 E. histolytica and/or E. dispar positives by PCR, microscopy and ELISA respectively. Six (7.2\%) E. histolytica, 72 (86.7\%) E. dispar and $5(6 \%)$ E. histolytica+E. dispar co-infections were detected out of 83 PCR positives and 24 of them were found to be negative by microscopy. Overall, the concordance of PCR and ELISA was found to be $69.1 \%$. The specificity and positive predictive values of ELISA compared to PCR were $82.7 \%$ and $72.1 \%$ respectively. In accordance with other studies, our results (87\% E. dispar infections) confirm that E. dispar is about ten times more prevalent in fecal samples than E. histolytica $(20,21)$.

A high prevalence of E. moshkovskii infection (21.1\%) has been detected in preschool children in Bangladesh (22). In another study, E. moshkovskii (1.1\%) was shown as a rare human parasitic infectious agent in asymptomatic cyst passers in Iran, a neighbouring country of Turkey (23). Two E. moshkovskii cases were also reported in Turkey (24). In the present study, 20 samples were found to be negative by PCR out of 79 microscopically positives. These 20 negatives can be explained by either having E. moshkovskii or presence of inhibition factors for PCR assay in stool samples. In ouropinion, there is a need for identification of E. moshkovskii in stool samples, especially for PCR negative and microscopically positive samples.

\section{CONCLUSION}

Accurate differentiation of invasive E. histolytica from the morphologically identical commensal E. dispar is crucial for clinical management of patients and epidemiological investigation of amebiasis. Although this study has been providing comparable results of microscopy, ELISA and PCR, none of these methods can detect all positives alone. According to our results, microscopy is a simple analysis, but it is subjective, needs experience to evaluate and should be combined with complimentary methods such as antigen detection and PCR for identification of the species to avoid false and/or insufficient diagnosis and treatment applications.

\section{Conflict of Interest}

No conflict of interest was declared by the authors.

Peer-review: Externally peer-reviewed.

Informed Consent: Written informed consent was obtained from patients who participated in this study.

\section{Author Contributions}

Concept- F.Y.Z., N.T.; Design - F.Y.Z., N.T., S.T.; Supervision - S.T., U.A.; Funding - N.T., S.T.; Materials - F.Y.Z., A.U.; Data Collection and/or Processing - F.Y.Z., N.T., A.U.; Analysis and/or Interpretation - F.Y.Z., S.T., N.T.; Literature Review - F.Y.Z., A.U., S.U.; Writer - F.Y.Z., N.T., S.T.; Critical Review - F.Y.Z., U.A., S.T., N.T., A.U., S.U.; Other - S.T., N.T.

\section{Acknowledgements}

We would like to thank to Dr. Hugues Charest (Canada) for supporting E. histolytica and E. dispar positive control DNA samp- 
les. We also thank Fehime Yavuz and Ibrahim Uygur for their technical assistance during the project. This work received financial support from Ege University Funds (Project No. 04 TIP 27).

\section{Çıkar Çatışması}

Yazarlar herhangi bir çıkar çatışması bildirmemişlerdir.

Hakem değerlendirmesi: Dış bağımsız.

Hasta Onamı: Yazılı hasta onamı bu çalışmaya katılan hastalardan alınmıştır.

\section{Yazar Katkıları}

Fikir - F.Y.Z., N.T.; Tasarım - F.Y.Z., N.T., S.T.; Denetleme - S.T., U.A.; Kaynaklar - N.T., S.T.; Malzemeler - F.Y.Z., A.U.; Veri toplanması ve/veya işlemesi - F.Y.Z., N.T., A.U.; Analiz ve/veya yorum F.Y.Z., S.T., N.T.; Literatür taraması - F.Y.Z., A.U., S.U.; Yazıyı yazan - F.Y.Z., N.T., S.T.; Eleştirel Inceleme - F.Y.Z., U.A., S.T., N.T., A.U., S.U.; Diğer - S.T., N.T.

\section{Teşekkür}

E. histolytica ve E. dispar kontrol DNA örneklerini gönderen Dr. Hugues Charest'e (Kanada) teşekkür ederiz. Ayrıca proje sırasındaki teknik destekleri için Fehime Yavuz ve Ibrahim uygur'a da teşekkür ederiz. Bu çalışma Ege Üniversitesi 04 TIP 27 Nolu BAP projesi ile desteklenmiştir.

\section{REFERENCES}

1. Radovanovica ZL, Katicb VV, Nagornic AV, Zivkovicb VV, Stankovicd TD, Trenkice MS. Clinical diagnostic problems associated with cecal ameboma. Case report and review of the literature. Pathol Res Pract 2007; 203: 823-5. [CrossRef]

2. World Health Organisation, World Health Organisation/Pan American Health Organisation/UNESCO report of a consultation of experts on amoebiasis. Wkly Epidemiol Rec WHO 1997; 72: 97-9.

3. Tannich E, Burchard GD. Differentiation of pathogenic from nonpathogenic Entamoeba histolytica by restriction fragment analysis of a single gene amplified in vitro. J Clin Microbiol 1991; 29: 250-5.

4. Braga LL, Gomes ML, Silva MW, Paiva C, Sales A, Mann BJ. Entamoeba histolytica and Entamoeba dispar infections as detected by monoclonal antibody in an urban slum in Fortaleza, Northeastern Brazil. Rev Soc Bras Med Trop 2001; 34: 467-71. [CrossRef]

5. Nunez YO, Fernandez MA, Torres-Nunez D, Silva JA, Montano I, Maestre JL, et al. Multiplex polymerase chain reaction amplification and differentiation of Entamoeba histolytica and Entamoeba dispar DNA from stool samples. Am J Trop Med Hyg 2001; 64: 293-7.

6. González-Ruiz A, Haque R, Aguirre A, Casta-ón G, Hall A, Guhl F, et al. Value of microscopy in the diagnosis of dysentery associated with invasive Entamoeba histolytica. J Clin Pathol 1994; 47: 236-9. [CrossRef]

7. Tanyüksel M, Yılmaz H, Ulukanlıgil M, Araz E, Çiçek M, Koru O, et al. Comparison of two methods (Microscopy and ELISA) for the diagnosis of amebiasis. Exp Parasitol 2005; 110: 322-6. [CrossRef]

8. Garcia LS, Bruckner DA. Diagnostic Medical Parasitology, 3rd ed., ASM: Washington, DC. 1997.

9. Gonin P, Trudel L. Detection and differentiation of Entamoeba histolytica and Entamoeba dispar isolates in clinical samples by PCR and enzyme-linked immunosorbent assay. J Clin Microbiol 2003; 41. 237-41. [CrossRef]

10. Haque R, Roy S, Siddique A, Mondal U, Rahman SMM, Mondal D, et al. Multiplex real-time PCR assay for detection of Entamoeba histolytica, Giardia intestinalis, and Cryptosporidium spp. Am J Trop Med Hyg 2007; 76: 713-7.

11. Solaymani-Mohammadi S, Rezaian M, Babaei Z, Rajabpour A, Meamar AR, Pourbabai AA, et al. Comparison of a Stool Antigen Detection Kit and PCR for Diagnosis of Entamoeba histolytica and Entamoeba dispar Infections in Asymptomatic Cyst Passers in Iran. J Clin Microbiol 2006; 44: 2258-61. [CrossRef]

12. Yildiz Zeyrek F, Ozbilge $H$, Yuksel MF, Zeyrek CD, Sirmatel F. Parasitic fauna and the frequency of Entamoeba histolytica/ Entamoeba dispar detected by ELISA in stool samples in Sanliurfa, Turkey. Türkiye Parazitol Derg 2006; 30: 95-8.

13. Haque R, Kress K, Wood S, Jackson TF, Lyerly D, Wilkins $T$, et al Diagnosis of pathogenic Entamoeba histolytica infection using a stool ELISA based on monoclonal antibodies to the galactose specific adhesin. J Infec Dis 1993; 167: 247-9. [CrossRef]

14. Lebbad M, Svard SG. PCR differentiation of Entamoeba histolytica and Entamoeba dispar from patients with amoeba infection initially diagnosed by microscopy. Scand J Infect Dis 2005; 37: 680-5. [CrossRef]

15. Paglia MG, Visca P. An improved PCR-based method for detection and differentiation of Entamoeba histolytica and Entamoeba dispar in formalin-fixed stools. Acta Trop 2004; 92: 273-7. [CrossRef]

16. Blessmann J, Buss $H$, Ton Nu PA, Dinh BT, Ngo QTV, Van AL, et al. Real-time PCR for detection and differentiation of Entamoeba histolytica and Entamoeba dispar in fecal samples. J Clin Microbiol 2002; 40: 4413-7. [CrossRef]

17. Calderaro A, Gorrini C, Bommezzadri S, Piccolo G, Dettori G, Chezzi C. Entamoeba histolytica and Entamoeba dispar: comparison of two PCR assays for diagnosis in a non-endemic setting. Trans R Soc Trop Med Hyg 2006; 100: 450-7. [CrossRef]

18. Paul J, Srivastava S, Bhattacharya S. Molecular methods for diagnosis of Entamoeba histolytica in a clinical setting: an overview. Exp Parasitol 2007; 116: 35-43. [CrossRef]

19. Romero JL, Descoteaux S, Reed S, Orozco E, Santos J, Samuelson $J$. Use of polymerase chain reaction and nonradioactive DNA probes to diagnose Entamoeba histolytica in clinical samples. Arch Med Res 1992; 23: 277-9.

20. Herbinger K.H, Fleischmann E, Weber C, Perona P, Loscher T, G. Bretzel. Epidemiological, clinical, and diagnostic data on intestinal infections with Entamoeba histolytica and Entamoeba dispar among returning travelers. Infection 2011; 39: 527-35. [CrossRef]

21. Stark D, van Hal S, Fotedar R, Butcher A, Marriott D, Ellis J, et al. Comparison of Stool Antigen Detection Kits to PCR for Diagnosis of Amebiasis. J Clin Microbiol 2008; 46: 1678-81. [CrossRef]

22. Ali IK, Hossain MB, Roy S, Ayeh-Kumi PF, Petri WA, Haque R, et al. Entamoeba moshkovskii infections in children, Bangladesh. Emerg Infect Dis 2003; 9: 580-4. [CrossRef]

23. Solaymani-Mohammadi S, Rezaian M, Babaei Z, Rajabpour A, Meamar AR, Pourbabai AA, et al. Comparison of a stool antigen detection kit and PCR for diagnosis of Entamoeba histolytica and Entamoeba dispar infections in asymptomatic cyst passers in Iran. J Clin Microbiol 2006; 44: 2258-61. [CrossRef]

24. Tanyuksel M, Ulukanligil M, Guclu Z, Araz E, Koru O, Petri WA. Two cases of rarely recognized infection with Entamoeba moshkovskii. Am J Trop Med Hyg 2007; 76: 723-4. 